\title{
Robo-Advising Risk Profiling through Content Analysis for Sustainable Development in the Hong Kong Financial Market
}

\author{
Mike K. P. So (it) \\ Department of Information Systems, Business Statistics and Operations Management, The Hong Kong University \\ of Science and Technology, Clear Water Bay, Hong Kong, China; immkpso@ust.hk; Tel.: +852-2358-7726
}

Citation: So, M.K.P. Robo-Advising Risk Profiling through Content

Analysis for Sustainable

Development in the Hong Kong Financial Market. Sustainability 2021, 13, 1306. https://doi.org/10.3390/ su13031306

Academic Editors: Klaus Reiner Schenk-Hoppé and Wing-Keung Wong

Received: 13 December 2020

Accepted: 24 January 2021

Published: 27 January 2021

Publisher's Note: MDPI stays neutral with regard to jurisdictional claims in published maps and institutional affiliations.

\begin{abstract}
Nowadays, we mainly depend on financial consultants or advisors to conduct risk assessments for individual investors before providing them with any investment advice or recommendations. Individual investors should understand the risk level of their investment choices and their investment decisions should match their risk profile. This process is usually conducted in face-to-face meetings. However, during the recent coronavirus disease 2019 pandemic, which has seriously impacted daily life with social distancing, in order to maintain sustainability, contact-free advising, such as robo-advising, becomes more important. The aim of this paper was to assess customers' risk in regards to investment and identify important risk factors needed to profile individual risk preferences, in order to prepare for robo-advising. Inductive content analysis is applied to classify 180 questions from 20 risk assessment questionnaires, sourced from banks and investment service providers, into different types. Then, the number of types is reduced by collapsing similar areas into broader higher order categories (the important risk factors). This paper also makes specific recommendations for the implementation of risk profiling in robo-advising.
\end{abstract}

Keywords: financial behavior; Fintech; investment advice; risk preference; robo-advising; sustainable finance

\section{Introduction}

With the remarkable development of Fintech in the financial industry in recent years, many traditional financial products and services are now available online. One of the areas of innovation is in robo-advising [1,2]. Robo-advising is a platform that consists of interactive and intelligent components, through which customers can receive personalized investment services online, instead of by making appointments with human advisors. It is expected to be the next step in the evolution of asset management and financial advice [3]. Further, to the enforcement of social distancing due to the coronavirus disease 2019 (COVID-19) pandemic, robo-advising is of great importance in the development of non-contact advisory services.

There are three major steps involved in robo-advising: product configuration, matching, and maintenance [1,4-6]. In the product configuration step, a robo-advisor identifies the customer's investment needs and objectives, and measures the risk and investment related to the customer based on profiling. In the matching step, a robo-advisor processes the collected information and generates a recommendation for the customer. In the maintenance step, a robo-advisor tracks the asset performance and reacts to changes by rebalancing the portfolio. In other words, risk profiling for robo-advising is the first step in achieving the sustainability of investment products and services, because a comprehensive risk assessment is not only a regulatory requirement but also builds trust and develops relationships with customers [7-9], as well as contributing to financial inclusion [10]. However, it is still at a nascent stage [11] and surprisingly little research has been conducted in this field $[7,12]$. Correspondingly, two important questions that may draw researchers' and practitioners' attention include: (i) What are the important risk factors for profiling customers' risk that we have to consider in robo-advising? (ii) How can we 
develop an organized and theoretical framework and protocol for systematic research on robo-advising?

There are two important behavioral theories on risk preference-expected utility theory and prospect theory. In expected utility theory [13-15], choices are coherently and consistently made by weighing the outcome of actions by their probabilities. If an investor is risk averse, $\mathrm{s} /$ he would refuse a fair gamble. A concavity of the utility function is expected. However, prospect theory suggests "several classes of choice problems in which preferences systematically violate the axioms of expected utility theory" (p. 263) [16]. It indicates that investors value losses and gains differently and they make decisions based on perceived gains rather than perceived losses [17]. We may conclude that risk preferences, tolerance, and attitudes are multi-dimensional and multitude and not easily assessed [18,19].

Currently, banks and investment service providers are used to adopt their own risk assessment or profiling questionnaires to collect customers' information relating to their attitudes toward risk and their risk tolerance [9] and the assessment results from the questionnaire is often a major input into the asset management and financial advice [20]. These financial institutions usually design the questionnaires and develop the questions with reference to scientific research and/or through their internal investment advisory teams [21]. In addition, the questionnaires have to meet the compulsory requirements of regulatory commissions. Though the accuracy of the questions may not be a problem, there is no recognized standard in regards to which questions to include or exclude, nor to determine the types of questions that should be asked or an appropriate length for the questionnaire [22]. This paper seeks to investigate the risk profiling questions commonly asked by banks and investment service providers to assess their customers' risk in regard to investments, and then aims to group them into different risk factors through content analysis. These important risk factors are recommended for inclusion as part of the robotassisted profiling of an investor's risk preference. We also make suggestions for the launch of such automated investment services.

\section{Materials and Methods}

We collected representative risk assessment questionnaires from banks and investment service providers (e.g., insurance and financial planning companies, and governmentsubvented fund management organizations) in both Hong Kong and outside of Hong Kong.

We first searched for risk assessment questionnaires through Google and Microsoft search engines, using the following key words: "risk assessment questionnaire", "risk profile questionnaire", "risk tolerance questionnaire", "investor profile questionnaire", and "investment risk profiling questionnaire". We gathered publicly available questionnaires from the targeted company types. Some of the questionnaires had a score assigned to each option in a question, so it was possible to compute our own risk grade or score by adding up the scores of all the options selected. We further obtained questionnaires via personal accounts and mobile apps. We needed to be existing customers of some companies to access their questionnaires. In these instances, when we completed a questionnaire online, we would receive a risk grade or score, but there would be no follow-up action from the companies. In total, we collected 20 questionnaires with 180 questions.

Of these 20 questionnaires, 11 are used in financial institutions in Hong Kong and one of them is used in a government-subvented fund management organization, while nine questionnaires are used outside Hong Kong. Non-Hong Kong financial institutions are located in various countries, including Australia, Canada, the UK, and the USA. The length of the questionnaires varies from six to 13 questions, excluding questions regarding personal information. The result of 14 questionnaires (10 from Hong Kong and four from overseas) is a risk class/score/tolerance level ranging from low to high risk, while the result of five questionnaires from outside Hong Kong provides a recommended asset allocation of different asset classes. One questionnaire from Hong Kong does not include a result. A summary of the questionnaires is shown in Table 1. We profiled the institutions 
that provided the questionnaires for our analysis: Five are commercial banks, seven are investment banks, seven provide insurance and/or financial planning services, and one is a government-subvented body. All of them are well-established institutions; some are market leaders. The backgrounds and the diversified business nature of the institutions provide strong evidence that the questionnaires are trustworthy and representative. A profile of the institutions is shown in Appendix A.

Table 1. List of the 20 Questionnaires: 11 from Hong Kong and Nine from Outside Hong Kong.

\begin{tabular}{|c|c|c|c|c|c|}
\hline & Company & Business Nature & Region & Number of Questions & Result \\
\hline 1 & $A^{\wedge}$ & $\begin{array}{c}\text { Insurance and } \\
\text { Financial Planning }\end{array}$ & Hong Kong & 11 & 3 risk categories from low to high \\
\hline 2 & $\mathrm{~B}$ & Commercial Bank & Hong Kong & 9 & Risk profiling score \\
\hline 3 & $\mathrm{C}$ & Commercial Bank & Hong Kong & 10 & 6 investor ratings from IR1 to IR6 \\
\hline 4 & $\mathrm{D}$ & Commercial Bank & Hong Kong & $\begin{array}{l}7+\text { Part I-Particulars } \\
\text { and Part II-General } \\
\text { Derivative Knowledge }\end{array}$ & 5 risk classes from $\mathrm{C} 1$ to $\mathrm{C} 5$ \\
\hline 5 & $\mathrm{E}$ & Commercial Bank & Hong Kong & $\begin{array}{l}9+\text { Part I-Customer } \\
\text { Information }\end{array}$ & 6 risk tolerance levels from 0 to 5 \\
\hline 6 & $\mathrm{~F}$ & $\begin{array}{l}\text { Government- } \\
\text { Subvented Fund } \\
\text { Management } \\
\text { Organization }\end{array}$ & Hong Kong & $\begin{array}{l}9+\text { Customer } \\
\text { Information }\end{array}$ & A score from 1 to 10 \\
\hline 7 & G & Commercial Bank & Hong Kong & 6 & 6 risk tolerance levels from 0 to 5 \\
\hline 8 & $\mathrm{H}$ & $\begin{array}{c}\text { Insurance and } \\
\text { Financial Planning }\end{array}$ & Hong Kong & 6 & 5 risk profiles from low to high \\
\hline 9 & $\mathrm{I}$ & Investment Bank & Hong Kong & $\begin{array}{c}13+\text { Part I-Personal } \\
\text { Details }\end{array}$ & / \\
\hline 10 & $J^{\wedge}$ & $\begin{array}{l}\text { Insurance and } \\
\text { Financial Planning }\end{array}$ & Hong Kong & 10 & $\begin{array}{c}5 \text { risk tolerance levels from low to } \\
\text { high }\end{array}$ \\
\hline 11 & K & $\begin{array}{c}\text { Insurance and } \\
\text { Financial Planning }\end{array}$ & Hong Kong & 7 & 5 risk levels from low to high \\
\hline 12 & $\mathrm{~L}$ & Investment Bank & USA & 10 & $\begin{array}{l}\text { A suggested allocation of different } \\
\text { asset classes (adding up to 100\%) }\end{array}$ \\
\hline 13 & $M^{\wedge}$ & Financial Planning & USA & 6 & $\begin{array}{l}5 \text { risk tolerance scales from low } \\
\text { to high }\end{array}$ \\
\hline 14 & $\mathrm{~N}^{\wedge}$ & Financial Planning & Australia & 10 & $\begin{array}{l}\text { Five investment strategies from } 30 \% \\
\text { growth to } 100 \% \text { growth }\end{array}$ \\
\hline 15 & $\mathrm{O}^{\wedge}$ & $\begin{array}{c}\text { Insurance and } \\
\text { Financial Planning }\end{array}$ & Canada & 8 & $\begin{array}{l}5 \text { risk profile classes from } \\
\text { conservative to aggressive }\end{array}$ \\
\hline 16 & $\mathrm{P}^{\wedge}$ & Investment Bank & USA & 9 & $\begin{array}{l}5 \text { suggested target allocations of } \\
\text { different asset classes }\end{array}$ \\
\hline 17 & Q & Investment Bank & UK & $\begin{array}{l}11+2 \text { preliminary } \\
\text { questions }\end{array}$ & $\begin{array}{l}6 \text { risk profile classes from minimal } \\
\text { risk to aggressive }\end{array}$ \\
\hline 18 & $\mathrm{R}$ & Investment Bank & Global & 7 & $\begin{array}{l}6 \text { risk profile classes from risk averse } \\
\text { to very aggressive }\end{array}$ \\
\hline 19 & $S^{\wedge}$ & Investment Bank & Canada & 10 & $\begin{array}{l}5 \text { suggested portfolios from } \\
\text { conservative to growth }\end{array}$ \\
\hline 20 & $\mathrm{~T}$ & Investment Bank & USA & 12 & $\begin{array}{l}\text { A suggested allocation of different } \\
\text { asset classes (adding up to 100\%) }\end{array}$ \\
\hline
\end{tabular}

^Score is shown next to each option for each question or at the end of the questionnaire so that the investor can calculate the result by adding up the scores of all options selected. 
We use inductive content analysis to examine the content of the questionnaires because no previous studies deal with this area; there is thus no theory to test [23]. The inductive approach identifies patterns through repeated observations and comparisons of the raw materials and then develops key themes through inductive reasoning, which reduces the number of specific observations to broad generalizations. Unlike quantitative research, qualitative research often concerns developing a depth of understanding rather than a breadth [24]. The question of what sample size is needed for qualitative research is frequently asked by individual researchers [25]. Some researchers suggest that qualitative sample sizes of ten may be adequate for sampling among a homogenous population [26]. In addition, in a meta-analysis of 560 academic qualitative studies, the distribution of sample sizes used was found to have sample sizes that were multiples of ten [27]. In this regard, the 20 questionnaires can be of importance and are useful to generate great insight.

First of all, the 180 questions are classified into different types of questions according to the manifest meanings both in the questions and the options available to the respondents. The number of types created is not pre-set and is solely based on examining the nature of the questions and their options to identify the numbers and types of similarities. In other words, all the types are derived directly from the questionnaires themselves.

Different companies have different styles in terms of how they ask questions. Taking the question type "Investment Time Horizon" as an example, one of the companies asks in a very direct manner:

Question: In general, what is the time period intended for your financial investment?

(a) Less than 1 year

(b) 1 year to less than 3 years

(c) 3 years to less than 5 years

(d) 5 years to less than 8 years

(e) 8 years or above

While another company puts it this way:

Question: When do you expect to start withdrawing your investment?

Above 20 years $\rightarrow 11-20$ years $\rightarrow 6-10$ years $\rightarrow 1-5$ years $\rightarrow$ Less than 1 year

By examining the two questions above and the options provided in answer to them, the two questions are obviously asking for the same information; we thus categorized them as the same type. As a result, about $97 \%$ of the 180 questions are grouped into 15 different types. The approximately $3 \%$ of unclassified questions are usually background information questions (e.g., "What is your total monthly income?") or firm-specific questions (e.g., "Please select up to six currencies you may consider for investments in this account"). The name of each type is simply a direct description of the nature and manifest meaning of the questions grouped under that type. For comparison purposes, we break down the "question type" distribution by Hong Kong questionnaires and non-Hong Kong questionnaires (Table 2), so that we can easily investigate whether or not there are any differences in questionnaire design between Hong Kong and overseas companies. Relatively, Types 1, 2, $3,4,6,7,9,10$, and 12 are popular questions, accounting for $79.4 \%$ of the 180 questions. We provide a brief summary of these classified types in Appendix B.

Table 2. Question type distribution by Hong Kong and overseas.

\begin{tabular}{cccccc}
\hline & & \multicolumn{2}{c}{ Hong Kong } & \multicolumn{2}{c}{ Overseas } \\
\hline & Type & $\begin{array}{c}\text { Number of } \\
\text { Questions }\end{array}$ & \% Total & $\begin{array}{c}\text { Number of } \\
\text { Questions }\end{array}$ & \% Total \\
\hline 1 & $\begin{array}{c}\text { Investment plan/goal and expected } \\
\text { return from investment }\end{array}$ & 12 & $12.4 \%$ & 10 & $12.0 \%$ \\
\hline 2 & Investment time horizon & 8 & $8.2 \%$ & 10 & $12.0 \%$ \\
\hline 3 & $\begin{array}{c}\text { Description of investment } \\
\text { knowledge and experience }\end{array}$ & 7 & $7.2 \%$ & 5 & $6.0 \%$ \\
\hline
\end{tabular}


Table 2. Cont.

\begin{tabular}{|c|c|c|c|c|c|}
\hline & \multirow[b]{2}{*}{ Type } & \multicolumn{2}{|c|}{ Hong Kong } & \multicolumn{2}{|c|}{ Overseas } \\
\hline & & $\begin{array}{l}\text { Number of } \\
\text { Questions }\end{array}$ & $\%$ Total & $\begin{array}{l}\text { Number of } \\
\text { Questions }\end{array}$ & $\%$ Total \\
\hline 4 & $\begin{array}{l}\text { Description of product knowledge } \\
\text { and trading experience }\end{array}$ & 7 & $7.2 \%$ & 3 & $3.6 \%$ \\
\hline 5 & Current asset allocation & 3 & $3.1 \%$ & 1 & $1.2 \%$ \\
\hline 6 & $\begin{array}{l}\text { Description of the degree of risk } \\
\text { willing to take in literal form }\end{array}$ & 7 & $7.2 \%$ & 16 & $19.3 \%$ \\
\hline 7 & $\begin{array}{c}\text { Description of the degree of risk } \\
\text { willing to take in quantitative form }\end{array}$ & 9 & $9.3 \%$ & 11 & $13.3 \%$ \\
\hline 8 & $\begin{array}{l}\text { Degree of risk tolerance when } \\
\text { experiencing investment loss } \\
\text { (hypothetical question) }\end{array}$ & 3 & $3.1 \%$ & 5 & $6.0 \%$ \\
\hline 9 & $\begin{array}{l}\text { Action would take when } \\
\text { experiencing investment loss } \\
\text { (hypothetical question) }\end{array}$ & 4 & $4.1 \%$ & 11 & $13.3 \%$ \\
\hline 10 & $\begin{array}{l}\text { Percentage of income/net worth for } \\
\text { investment }\end{array}$ & 9 & $9.3 \%$ & 1 & $1.2 \%$ \\
\hline 11 & Earning capacity of an investor & 2 & $2.1 \%$ & 1 & $1.2 \%$ \\
\hline 12 & $\begin{array}{l}\text { Financial health check and } \\
\text { employment status }\end{array}$ & 9 & $9.3 \%$ & 4 & $4.8 \%$ \\
\hline 13 & Age/education level of the investor & 7 & $7.2 \%$ & 1 & $1.2 \%$ \\
\hline 14 & $\begin{array}{l}\text { Confidence in making own } \\
\text { investment decisions }\end{array}$ & 1 & $1.0 \%$ & 3 & $3.6 \%$ \\
\hline 15 & $\begin{array}{l}\text { Withdrawing money from } \\
\text { investments to fill liquidity needs }\end{array}$ & 4 & $4.1 \%$ & 1 & $1.2 \%$ \\
\hline \multirow[t]{2}{*}{16} & Others & 5 & $5.2 \%$ & 0 & $0 \%$ \\
\hline & Total & 97 & $100 \%$ & 83 & $100 \%$ \# \\
\hline
\end{tabular}

\# Not adding up to $100 \%$ due to rounding.

\section{Results}

We can observe the common and uncommon elements in the Hong Kong questionnaires and overseas questionnaires by comparing the typical types of questions, as shown in Table 2.

\subsection{Typical Types of Questions}

\subsubsection{Typical Types of Questions for Both Hong Kong and Overseas Questionnaires}

Types 1, 2, 6, and 7 are the most commonly asked questions in both the Hong Kong questionnaires and the overseas questionnaires. They account for a total of $37.1 \%$ of the questions in the Hong Kong questionnaires and more than half (56.6\%) of the questions in the overseas questionnaires (Table 3). Types 6 and 7 are even more popular in the overseas questionnaires than in the Hong Kong questionnaires, representing $32.6 \%(=19.3 \%+13.3 \%)$ and $16.5 \%(=7.2 \%+9.3 \%)$ of questions, respectively. Moreover, nine out of the 11 Type 7 questions in the overseas questionnaires include a data visualization effect in the options, while only one out of the nine Type 7 questions in the Hong Kong questionnaires provides graphs in the options. This indicates that overseas financial/investment service providers concentrate more on asking questions belonging to Types 6 and 7 with the use of data visualization in order to make the questions more understandable. 
Table 3. Most common types of questions in both Hong Kong and overseas questionnaires.

\begin{tabular}{cccccc}
\hline & & \multicolumn{2}{c}{ Hong Kong } & \multicolumn{2}{c}{ Overseas } \\
\hline & Type & $\begin{array}{c}\text { Number of } \\
\text { Questions }\end{array}$ & \% Total & $\begin{array}{c}\text { Number of } \\
\text { Questions }\end{array}$ & \% Total \\
\hline 1 & $\begin{array}{c}\text { Investment plan/goal and expected } \\
\text { return from investment }\end{array}$ & 12 & $12.4 \%$ & 10 & $12.0 \%$ \\
\hline 2 & Investment time horizon & 8 & $8.2 \%$ & 10 & $12.0 \%$ \\
\hline 6 & $\begin{array}{c}\text { Description of the degree of risk } \\
\text { willing to take in literal form }\end{array}$ & 7 & $7.2 \%$ & 16 & $19.3 \%$ \\
\hline 7 & $\begin{array}{c}\text { Description of the degree of risk } \\
\text { willing to take in quantitative form }\end{array}$ & 9 & $9.3 \%$ & 11 & $13.3 \%$ \\
\hline & Total & 36 & $37.1 \%$ & 47 & $56.6 \%$ \\
\hline
\end{tabular}

On top of the above-mentioned types of questions, Type 3 (description of investment knowledge and experience) and Type 4 (description of product knowledge and trading experience) are also common types of questions for both the Hong Kong questionnaires and the overseas questionnaires. Type 3 accounts for $7.2 \%$ of the questions in the Hong Kong questionnaires and $6.0 \%$ of the questions in the overseas questionnaires. Type 4 represents another $7.2 \%$ of the questions in the Hong Kong questionnaires and $3.6 \%$ of the questions in the overseas questionnaires.

\subsubsection{Types of Questions Typical for Hong Kong but Not for Overseas Questionnaires}

Two types of questions (Types 10 and 12) are typical for the Hong Kong questionnaires but not for the overseas questionnaires (Table 4). They account for a total of $18.6 \%$ of the questions in the Hong Kong questionnaires, compared with only $6 \%$ of the questions in the overseas questionnaires. This reflects the way in which financial/investment service providers in Hong Kong are more concerned about the financial strength of individual investors.

Table 4. Types of questions typical in Hong Kong but not in overseas questionnaires.

\begin{tabular}{cccccc}
\hline & & \multicolumn{2}{c}{ Hong Kong } & \multicolumn{2}{c}{ Overseas } \\
\hline Type & $\begin{array}{c}\text { Number of } \\
\text { Questions }\end{array}$ & \% Total & $\begin{array}{c}\text { Number of } \\
\text { Questions }\end{array}$ & \% Total \\
\hline 10 & $\begin{array}{c}\text { Percentage of income/net } \\
\text { worth for investment }\end{array}$ & 9 & $9.3 \%$ & 1 & $1.2 \%$ \\
\hline 12 & $\begin{array}{c}\text { Financial health check and } \\
\text { employment status }\end{array}$ & 9 & $9.3 \%$ & 4 & $4.8 \%$ \\
\hline Total & 18 & $18.6 \%$ & 5 & $6.0 \%$ \\
\hline
\end{tabular}

\subsubsection{Type of Questions Typical for Overseas but Not for Hong Kong Questionnaires}

Only one type of question (Type 9) is typical for the overseas questionnaires but not for the Hong Kong questionnaires (Table 5). It accounts for $13.3 \%$ of the questions in the overseas questionnaires, compared with only $4.1 \%$ of the questions in the Hong Kong questionnaires. This reflects the way in which overseas financial/investment service providers, instead of placing more emphasis on the financial strength of individual investors, are interested in knowing more about the actions taken by individual investors under investment loss. 
Table 5. Type of Questions Typical in Overseas but Not in Hong Kong Questionnaires.

\begin{tabular}{ccccc}
\hline & \multicolumn{2}{c}{ Hong Kong } & \multicolumn{2}{c}{ Overseas } \\
\hline Type & $\begin{array}{c}\text { Number of } \\
\text { Questions }\end{array}$ & \% Total & $\begin{array}{c}\text { Number of } \\
\text { Questions }\end{array}$ & \% Total \\
\hline 9 & 4 & $4.1 \%$ & 11 & $13.3 \%$ \\
\hline & $\begin{array}{c}\text { Action would take when } \\
\text { experiencing investment loss } \\
\text { (hypothetical question) }\end{array}$ & 4 & & \\
\hline
\end{tabular}

3.1.4. Least Frequently Asked Types of Questions for Both Hong Kong and Overseas Questionnaires

Six types of questions (Types 5, 8,11,13,14, and 15) are relatively less frequently asked in both the Hong Kong questionnaires and the overseas questionnaires (Table 6). Most of them account for only $1 \%$ to $4 \%$ of the questions in both the Hong Kong questionnaires and the overseas questionnaires. They could be just for supplementary purposes.

Table 6. Least frequently asked types of questions in both Hong Kong and overseas questionnaires.

\begin{tabular}{lccccc}
\hline & & \multicolumn{2}{c}{ Hong Kong } & \multicolumn{2}{c}{ Overseas } \\
\hline & Type & $\begin{array}{c}\text { Number of } \\
\text { Questions }\end{array}$ & \% Total & $\begin{array}{c}\text { Number of } \\
\text { Questions }\end{array}$ & \% Total \\
\hline 5 & Current asset allocation & 3 & $3.1 \%$ & 1 & $1.2 \%$ \\
\hline 8 & $\begin{array}{c}\text { Degree of risk tolerance when } \\
\text { experiencing investment loss } \\
\text { (hypothetical question) }\end{array}$ & 3 & $3.1 \%$ & 5 & $6.0 \%$ \\
\hline 11 & Earning capacity of an investor & 2 & $2.1 \%$ & 1 & $1.2 \%$ \\
\hline 13 & Age/education level of the investor & 7 & $7.2 \%$ & 1 & $1.2 \%$ \\
\hline 14 & $\begin{array}{c}\text { Confidence in making own } \\
\text { investment decisions }\end{array}$ & 1 & $1.0 \%$ & 3 & $3.6 \%$ \\
\hline 15 & $\begin{array}{c}\text { Withdrawing money from } \\
\text { investments to fill liquidity needs }\end{array}$ & 4 & $4.1 \%$ & 1 & $1.2 \%$ \\
\hline & Total & 20 & $20.6 \%$ & 12 & $4.4 \%$ \\
\hline
\end{tabular}

\subsection{Risk Factors to Be Considered}

After creating the 15 different types of questions and examining their popularity in the Hong Kong questionnaires and the overseas questionnaires, the next stage of content analysis is to reduce the number of types by collapsing some of the similar ones into broader and higher order categories [28]. In our work here, these broader and higher order categories are the important risk factors in regards to profiling individual risk preferences in robo-advising. These risk factors are not only bringing together types that are similar; additionally, those belonging to one risk factor should not relate to others classified as other risk factors $[29,30]$. We base our decisions on the questionnaire analysis and reference the literature to determine the risk factors.

For both Hong Kong and overseas questionnaires, the two major types of information collected from individual investors concern customers' ability and willingness to take risks. The ability to take risks is measured by factual information, such as a customer's financial situation, investment plan/goal, and investment time horizon, while the willingness to take risks is based on perceptual information, such as the degree of investment loss a customer could accept, and behavioral information, such as the actions a customer would take during a market downturn. These are consistent with Cordell's [31] suggestions that investment risk tolerance can be separated into four components: propensity (observed risk behavior in naturally occurring situations), attitude (willingness to incur monetary risk; for example, as measured by responses to hypothetical investment scenarios), capacity (financial capability 
to incur risk), and knowledge (for example, risk-return trade-offs). Individual investors are not machines; they have feelings and emotions. Including behavior-related questions will give a more complete understanding of investor risk preference.

As a result of the above content analyses, we consider only the nine most popular question types (Types 1, 2, 3, 4, 6, 7, 9, 10, and 12). They are grouped into five important risk factors (Factor I to Factor $\mathrm{V}$, as described below). We do not consider the remaining six question types (Type 5, 8, 11, 13,14, and 15) because they are the least popular questions in both the Hong Kong questionnaires and the overseas questionnaires. Other reasons not to consider these six question types include: (i) a long risk profiling assessment in robo-advising may lead to customer fatigue; and (ii) customers may be reluctant to answer questions they feel are unnecessary [32]. The importance of the five risk factors is discussed in the following sections.

\subsubsection{Factor I: The Setting of Realistic Investment Objectives/Goals (Factual Information)}

The following types of questions belong to Factor I.

- Type 1: Investment plan/goal and expected return from investment.

- Type 2: Investment time horizon.

We group Types 1 and 2 into one risk factor and name it the "setting of realistic investment objectives/goals". It serves two purposes. The first is to check whether or not the investment objectives/goals set up by an investor can be realistically achieved or could be achieved in practice. For example, if an investor wants to buy real estate in a prime area in three years through investment, this should be considered as an unrealistic goal. The second is to validate the investor's response to questions related to willingness to take risks. For example, if capital preservation is important to an investor and, at the same time, the investor can accept high levels of volatility in price movement, the investor is inconsistent in answering the questionnaire.

\subsubsection{Factor II: The Risk Appetite of an Investor (Perceptual Information)}

The following types of questions belong to Factor II.

- $\quad$ Type 6: Description of the degree of risk willing to take in literal form.

- $\quad$ Type 7: Description of the degree of risk willing to take in quantitative form.

This factor measures the degree of risk an investor is willing to take, on a spectrum from risk averse (conservative) to risk tolerant (aggressive). However, it may simply reflect what an investor thinks or what his or her perception is. No one can really predict how an investor will react when risky events do occur. Therefore, answers to this factor should be cross-checked with Factor I (in Section 3.2.1) and Factor IV (in Section 3.2.4).

3.2.3. Factor III: Understanding of Investment Risk According to Own Practical Experience and Knowledge (Investment Knowledge and Experience)

The following types of questions belong to Factor III.

- $\quad$ Type 3: Description of investment knowledge and experience.

- $\quad$ Type 4: Description of product knowledge and trading experience.

The third risk factor (Factor III) includes investment knowledge and experience, as well as product knowledge and trading experience, which all play important roles in evaluating investors' risk preference [33].

This factor reflects to what extent an investor understands the risks involved in the course of investments according to his or her practical investment experience and his or her investment knowledge. This understanding should be much more in-depth than the explanation of risks by a financial consultant. As a result, the risk class based on the responses from the questions should be much more reliable, indicating whether or not this kind of investor can comfortably tolerate higher risks. 
3.2.4. Factor IV: Investor Behavior when Suffering Investment Loss (Behavioral Information)

The following type of question belongs to Factor IV.

- $\quad$ Type 9: Action would take when experiencing investment loss (hypothetical question).

The fourth risk factor includes only one question type: Type 9. This type is very popular in the overseas questionnaires but not in the Hong Kong questionnaires. It constitutes $13.3 \%$ of the questions in the overseas questionnaires. Considering overseas factors makes a risk profiling assessment more international. Moreover, this behavioral type of question is one of the four key components in investment risk tolerance highlighted in Cordell's research [31].

This factor provides us with information about how investors would behave when suffering investment losses. It validates the results of Factor III. This factor also reflects the focus of overseas questionnaires. Suppose that an investor was aggressive, according to Factor II, and sold most of his or her investments during a significant drop in his or her portfolio value (which may be caused by emotional feelings or frustration, rather than personal liquidity problems); in this situation, a higher risk class should not be assigned.

\subsubsection{Factor V: Ability to Take Risks (Factual Information)}

The following types of questions belong to Factor V.

- $\quad$ Type 10: Percentage of income/net worth for investment.

- $\quad$ Type 12: Financial health check and employment status.

The fifth risk factor is identified among the common types of questions (Types 10 and 12) in the Hong Kong questionnaires but not in the overseas questionnaires. Each type constitutes $9.3 \%$ of the questions in the Hong Kong questionnaires, the second most common question type besides Type I (12.4\%).

This factor checks the strength of an investor's financial health and the income earning capacity of investors. If an investor has many more assets than liabilities, with a stable or even growing income, the investor has enough of a cushion to maintain his or her investment strategy, as advised by a financial consultant, even during downturn periods in financial markets. For example, an investor could still pay the monthly contributions for his or her investment plan in difficult times, so the expected long-term investment return could be realized. This kind of investor should invest in risky asset classes to achieve long-term capital gain. This factor also reflects the concerns of Hong Kong questionnaires.

\section{Reliability and Validity}

The reliability and validity of the factor identification process must be considered. As with all methodologies, reliability and validity are the most fundamental issues associated with the application of content analysis [34]. The author in [34] suggests: "To make valid inferences from the text, it is important that the classification procedure be reliable in the sense of being consistent: Different people should code the same text in the same way. Also, the classification procedure must generate variables that are valid" (p. 12). Two methods of checking for reliability and validity were used in the present study.

First, we asked a research assistant who was not involved in any other aspect of this study but was familiar with the process of category generation in content analysis to read through the 20 questionnaires, then create his own identification systems and identify risk factors independently. We then compared and discussed our work. To further ensure the classification was clear and representative enough, we invited an academic in finance and a risk professional to review the classification and risk factors identified. The reviewers agreed with the classification and risk factors identified. Only minor changes to the wording were made.

The second check for reliability and validity is to cross-validate the findings with the risk assessment questionnaires designed by other recognized international financial institutions not included in the sample of this study. Their questionnaires are available 
only to their existing customers. Deloitte and Wealthfront $[35,36]$ do not disclose their questionnaires but they do share the methodologies they use to assess individual risk preference on their own websites. Their common characteristics are the use of several factors to determine the risk score/category of a customer. Each factor consists of several questions in the questionnaire. These factors can be broadly described as the ability to take risks, tolerance of risk, and attitude toward risk. Information concerning these factors is obtained both directly and indirectly from the questions related to investment goals, investment experience, and hypothetical market situations, etc. Exploring the design of the questionnaires used by these two financial institutions enhances the reliability and validity of our findings.

\section{Discussion}

There exists no extant comprehensive analysis of the methods involved in roboadvising and calls have thus been made for more research on robo-advising [37-39]. In this study, we use content analysis to understand existing risk assessment and identify patterns through the investigation and comparisons on the 180 questions in the 20 questionnaires. We then develop five important risk factors to profile individual risk preference through inductive reasoning. This can help us to set boundary to build theory for robo-advising risk profiling [40]. The analysis results match Bhatia et al.'s [11] idea to design a robo-advisory service based on investors' profiles, risk tolerance, and risk analysis, as well as Singh and Kaur's [41] suggestion to consider risk tolerance, stage in life, net worth, experience with investments, and investment objectives in wealth management.

How different banks and investment service providers make use of the five identified risk factors in the assessment of individual risk preference through robo-advising could vary. The methods used should comply with company risk policies and align with its business strategies. In regards to the construction of risk assessment questionnaires, such as how to design a question, how many questions should be derived from each risk factor, how much weight should be carried by each factor, and how to calculate the final risk scores/grades, it is recommended that practitioners draft a preliminary version first and then conduct a customer survey to collect customer feedback. It is then possible to validate the risk assessment results with the customer data. For example, a sample of customers who hold or have ever held investment products could be invited to complete a draft version of the risk profiling online. Next, their feedback can be gathered to fine-tune the questionnaire and their preliminary risk scores/grades can be cross-checked with the risk categories of the investment products at hand. An extra benefit of a customer survey is that it enables research into customers' adoption of robo-advising.

In addition to integrating these five risk factors into the risk profiling assessment, we make five crucial implementation recommendations below in order to make the risk profiling involved in robo-advising even more successful.

First, the total number of questions should be limited to make the message clear that this assessment is much simpler and briefer than human assessments have been in the past. Second, questions should be simple and straightforward, to allow customers to provide valid responses instantly without the help of human consultants. Third, customer responses throughout the assessment should be consistent. If response inconsistency exists across any risk factors, the robot should prompt the customer to re-input the responses. Fourth, the risk scores/grades should be updated on a regular basis and the next update time should be determined by the company hosting the robo-advising. The information provided by investors is primarily based on one's own perceptions and investment decisions are mostly driven by emotions. Hence, the degree of risk one could take or how much loss one could bear is likely to change from time to time, especially when suffering investment loss. This reminds those with new experience of the price fluctuation of their investment products to review their risk preference. The last recommendation is that customers cannot ask to adjust their risk scores/grades within a short period of time, to avoid customers timing 
the market by buying investment products with risk grades higher than their original risk score/grade.

Two challenges presented by robo-advising are the lack of personal customization available for clients [42] and the lack of confidence in the ability of algorithms to perform tasks [43]. From a theoretical viewpoint, this study is a useful starting point for the development of an organized and theoretical framework and protocol for systematic research on robo-advising. It also represents a critical starting point for the development of methodology that can be used to evaluate risk and to recommend appropriate services and products to clients who have different risk preferences and needs. These elements are important in building trust with customers. Regarding practical significance, with our findings, managers can gain a better understanding of the questions that are useful for risk profiling and ways in which to develop risk profiling for robo-advising.

\section{Conclusions}

Robo-advising has become increasingly important for the sustainability of investments, as it can not only minimize costs and enable $24 / 7$ services, but is also contact free $[44,45]$. Financial institutions providing wealth management have to make a sound risk profiling model [11]. However, there is no recognized standard for the robot-assisted profiling of an investor's risk preferences and there are limited numbers of studies on robo-advising in the literature. The current study attempts to fill in this research gap. It develops a framework on risk profiling through content analysis and provides answers in regards to what kinds of questions are relevant to clients' risk profiling and how to assess their relevance.

In this study, we focus on the Hong Kong environment, but similar research can be replicated in other regions or countries, subject to their cultural, economic, and financial characteristics. Future research could also compare differences in the risk profiling of roboadvising in different regions or countries, and develop a methodological framework for personalized services offered through robo-advising. To the best of our knowledge, this is a pioneering study in the field of profile risk and robo-advising. The present study provides an organized and theoretical framework for researchers to use when conducting further studies aiming to integrate individual investors' risk preferences into robo-advising.

Funding: This research was funded by the Hong Kong RGC Theme-based Research Scheme, grant number T31-604/18-N.

Institutional Review Board Statement: Not applicable as the current study does not involve humans or animals.

Informed Consent Statement: Not applicable.

Data Availability Statement: No new data were created or analyzed in this study. Data sharing is not applicable to this article.

Conflicts of Interest: The author declares no conflict of interest.

\section{Appendix A}

Table A1. Profile of the Financial Institutions (in alphabetical order).

\begin{tabular}{|c|c|c|}
\hline Company & Website & Remarks from the Company \\
\hline \multicolumn{3}{|c|}{ Hong Kong } \\
\hline AIA & https://www.aia.com.hk & $\begin{array}{l}\text { AIA is the largest independent publicly listed } \\
\text { pan-Asian life insurance group. }\end{array}$ \\
\hline China Construction Bank (Asia) & https://www.asia.ccb.com & $\begin{array}{l}\text { It is the comprehensive and integrated commercial } \\
\text { banking platform of China Construction Bank } \\
\text { Corporation in Hong Kong. }\end{array}$ \\
\hline
\end{tabular}


Table A1. Cont.

\begin{tabular}{|c|c|c|}
\hline Company & Website & Remarks from the Company \\
\hline Citibank (Hong Kong) & https://www.citibank.com.hk & $\begin{array}{l}\text { Citi, the leading global bank, has approximately } \\
200 \text { million customer accounts and does business } \\
\text { in more than } 160 \text { countries and jurisdictions. }\end{array}$ \\
\hline DBS Hong Kong & https://www.dbs.com.hk & $\begin{array}{l}\text { DBS is a leading financial services group in Asia } \\
\text { with a presence in } 18 \text { markets. }\end{array}$ \\
\hline Hang Seng Bank & https://www.hangseng.com & $\begin{array}{l}\text { Hang Seng is one of Hong Kong's largest listed } \\
\text { companies. }\end{array}$ \\
\hline $\begin{array}{l}\text { Hong Kong Investment Fund } \\
\text { Association }\end{array}$ & https:/ /www.hkifa.org.hk & $\begin{array}{l}\text { It is a non-profit-making industry organization } \\
\text { that represents the fund management industry of } \\
\text { Hong Kong. }\end{array}$ \\
\hline HSBC & https://www.hsbc.com & $\begin{array}{l}\text { It is one of the largest banking and financial } \\
\text { services organizations in the world, with } \\
\text { operations in } 64 \text { countries and territories. }\end{array}$ \\
\hline $\begin{array}{l}\text { Manulife Asset Management } \\
\text { (Hong Kong) }\end{array}$ & https:/ / www.manulife.com.hk & $\begin{array}{l}\text { Manulife is the number one mandatory provident } \\
\text { fund (MPF) scheme sponsor in Hong Kong based } \\
\text { on assets under management and net cash flows. }\end{array}$ \\
\hline $\begin{array}{c}\text { Schroder Investment } \\
\text { Management (Hong Kong) }\end{array}$ & https://www.schroders.com & $\begin{array}{l}\text { Schroders continues to be one of the } 100 \text { largest } \\
\text { companies on the London Stock Exchange, where } \\
\text { it has been listed since } 1959 .\end{array}$ \\
\hline Standard Life (Asia) & https://www.standardlife.hk & $\begin{array}{c}\text { The company is based in Hong Kong, with eyes on } \\
\text { the Greater Bay Area and regional markets. }\end{array}$ \\
\hline Sun Life Hong Kong & https://www.sunlife.com.hk & $\begin{array}{l}\text { The company has been established in Hong Kong } \\
\text { for } 128 \text { years. }\end{array}$ \\
\hline
\end{tabular}

Overseas

Charles Schwab https://www.schwab.com

Edward Jones

https:/ / www.edwardjones.com

Lowe Lippmann Trakman

https:/ / www.lltfs.com.au

https:/ /www.manulife.ca

https:/ / www.merrilledge.com

Merrill Edge

https: / / www.morningstar.co.uk

Morningstar

https:/ / www.sc.com

Standard Chartered Global

https:/ / sunlifeglobalinvestments.com

Sun Life Global Investments

Vanguard

https:/ / vanguard.com
The company provides a full range of brokerage, banking, and financial advisory services through its operating subsidiaries.

The company serves nearly 7 million investors from more offices than any other investment firm in America.

Established in 1992, the company aims to provide individual and corporate clients in Melbourne and all across Australia with high-quality, personalized financial advice and services, covering all aspects of financial planning.

Manulife is a leading international financial services group.

It is an electronic trading platform provided by Bank of America's retail banking division.

The company provides an array of investment research and investment management services.

It is listed on the London and Hong Kong Stock Exchanges.

The company has become one of the fastest-growing retail and institutional managers in Canada.

Vanguard is one of the world's largest investment companies, offering a large selection of low-cost mutual funds, ETFs, advice, and related services. 


\section{Appendix B}

Table A2. Brief summary of question types.

\begin{tabular}{|c|c|c|c|c|c|}
\hline & Question Type & $\begin{array}{l}\text { Keywords Used in } \\
\text { the Question }\end{array}$ & $\begin{array}{l}\text { Keywords Used in } \\
\text { the Option }\end{array}$ & $\begin{array}{c}\text { Any Number or Percentage } \\
\text { in the Option? }\end{array}$ & $\begin{array}{l}\text { Any Graphs in } \\
\text { the Option? }\end{array}$ \\
\hline 1 & $\begin{array}{l}\text { Investment plan/goal } \\
\text { and expected return } \\
\text { from investment }\end{array}$ & $\begin{array}{l}\text { Investment goal, } \\
\text { investment objective, } \\
\text { risk, and return }\end{array}$ & $\begin{array}{l}\text { Capital preservation, } \\
\text { capital growth, } \\
\text { income generation, } \\
\text { price fluctuation, } \\
\text { inflation, and } \\
\text { deposit rates }\end{array}$ & $\begin{array}{c}\text { Few questionnaires provide } \\
\text { return rate }(\%) \text { in the } \\
\text { options }\end{array}$ & No \\
\hline 2 & $\begin{array}{l}\text { Investment time } \\
\text { horizon }\end{array}$ & $\begin{array}{l}\text { Investment horizon } \\
\text { and start withdrawing } \\
\text { money }\end{array}$ & $\begin{array}{l}\text { Less than, more than, } \\
\text { and years }\end{array}$ & $\begin{array}{l}\text { Most of the questionnaires } \\
\text { have an option regarding } \\
\text { investment time range in } \\
\text { years }\end{array}$ & No \\
\hline 3 & $\begin{array}{c}\text { Description of } \\
\text { investment knowledge } \\
\text { and experience }\end{array}$ & $\begin{array}{l}\text { Investment knowledge } \\
\text { and experience }\end{array}$ & $\begin{array}{l}\text { Limited, good, and } \\
\text { extensive }\end{array}$ & $\begin{array}{l}\text { Only some of the Hong } \\
\text { Kong questionnaires have } \\
\text { options regarding } \\
\text { investment knowledge in } \\
\text { year range }\end{array}$ & No \\
\hline 4 & $\begin{array}{l}\text { Description of product } \\
\text { knowledge and } \\
\text { trading experience }\end{array}$ & $\begin{array}{l}\text { Stocks, bonds, funds, } \\
\text { ETF, investment } \\
\text { knowledge and } \\
\text { experience }\end{array}$ & $\begin{array}{l}\text { Stocks, equities, } \\
\text { bonds, and funds }\end{array}$ & No & No \\
\hline 6 & $\begin{array}{l}\text { Description of the } \\
\text { degree of risk willing } \\
\text { to take in literal form }\end{array}$ & $\begin{array}{c}\text { Risk, return, } \\
\text { fluctuation, and } \\
\text { attitude }\end{array}$ & $\begin{array}{l}\text { Risk, return, growth, } \\
\text { higher, more, long } \\
\text { term, accept, and } \\
\text { willing }\end{array}$ & No & No \\
\hline 7 & $\begin{array}{l}\text { Description of the } \\
\text { degree of risk willing } \\
\text { to take in quantitative } \\
\text { form }\end{array}$ & $\begin{array}{c}\text { Portfolio, fluctuation, } \\
\text { comfortable, gain, and } \\
\text { loss }\end{array}$ & $\begin{array}{l}\text { Return, gain, loss, } \\
\text { and fluctuation }\end{array}$ & $\begin{array}{l}\text { Most of the questionnaires } \\
\text { provide portfolio return } \\
\text { rates }(\%) \text { in the options }\end{array}$ & Yes * \\
\hline 9 & $\begin{array}{l}\text { Action would take } \\
\text { when experiencing } \\
\text { investment loss } \\
\text { (hypothetical question) }\end{array}$ & $\begin{array}{l}\text { Experience, decline, } \\
\text { fall/fell, and loss/lost }\end{array}$ & $\begin{array}{l}\text { Sell, buy, keep, and } \\
\text { hold }\end{array}$ & No & No \\
\hline 10 & $\begin{array}{l}\text { Percentage of } \\
\text { income /net worth for } \\
\text { investment }\end{array}$ & $\begin{array}{l}\text { Percentage, income, } \\
\text { net worth, and } \\
\text { investment }\end{array}$ & $\begin{array}{l}\text { Less than and more } \\
\text { than }\end{array}$ & $\begin{array}{l}\text { All of the questionnaires } \\
\text { display options in terms of } \\
\text { percentage range }\end{array}$ & No \\
\hline 12 & $\begin{array}{l}\text { Financial health check } \\
\text { and employment } \\
\text { status }\end{array}$ & $\begin{array}{l}\text { Liquid, asset, expenses, } \\
\text { financial situation, and } \\
\text { job status }\end{array}$ & $\begin{array}{l}\text { Income and } \\
\text { expenses }\end{array}$ & $\begin{array}{l}\text { Only some of the Hong } \\
\text { Kong questionnaires have } \\
\text { options regarding time } \\
\text { range to use up the reserves } \\
\text { to cover expenses to meet } \\
\text { unforeseeable events }\end{array}$ & No \\
\hline
\end{tabular}

* Almost all of the overseas questionnaires use graphs to show the loss and gain involved in hypothetical portfolios.

\section{References}

1. Jung, D.; Dorner, V.; Weinhardt, C.; Pusmaz, H. Designing a robo-advisor for risk-averse, low-budget consumers. Electron. Mark. 2018, 28, 367-380. [CrossRef]

2. Chen, M.A.; Wu, Q.; Yang, B. How valuable is FinTech innovation? Rev. Financ. Stud. 2019, 32, 2062-2106. [CrossRef]

3. A.T. Kearney. Hype vs. Reality: The Coming Waves of Robo-Advisors. 2015. Available online: https://www.kearney.com/ documents/20152/4956162/Hype+vs.+Reality_The+Coming+Waves+of+Robo+Adoption.pdf/7933ae48-8f0c-124a-c84d-00 $7 \mathrm{e} 96190276 ? \mathrm{t}=1545110266951$ (accessed on 27 January 2021). 
4. Jung, D.; Glaser, F.; Köpplin, W. Robo-advisory: Opportunities and risks for the future of financial advisory. In Advances in Consulting Research; Springer: Cham, Switzerland, 2018; pp. 405-427.

5. Cocca, T.D. Potential and limitations of virtual advice in wealth management. J. Financ. Transform. 2016, 44, 45-57.

6. Sironi, P. FinTech Innovation: From Robo-Advisors to Goal Based Investing and Gamification; The Wiley Finance Series; John Wiley \& Sons Ltd.: Hoboken, NJ, USA, 2016.

7. Jung, D.; Dorner, V.; Glaser, F.; Morana, S. Robo-advisory: Digitalization and automation of financial advisory. Bus. Inf. Syst. Eng. 2018, 60, 81-86. [CrossRef]

8. Cheng, X.; Guo, F.; Chen, J.; Li, K.; Zhang, Y.; Gao, P. Exploring the trust influencing mechanism of robo-advisor service: A mixed method approach. Sustainability 2019, 11, 4917. [CrossRef]

9. Linciano, N.; Soccorso, P. Assessing Investors' Risk Tolerance through a Questionnaire; Commissione Nazionale per le Società e la Borsa (Consob): Rome, Italy, 2012.

10. Kaya, O. Robo-Advice: A True Innovation in Asset Management. 2017. Available online: https://www.dbresearch.com/PROD/ RPS_EN-PROD/PROD0000000000449125/Robo-advice_\%E2\%80\%93_a_true_innovation_in_asset_managemen.PDF (accessed on 20 October 2020).

11. Bhatia, A.; Chandani, A.; Chhateja, J. Robo advisory and its potential in addressing the behavioral biases of investors: A qualitative study in Indian context. J. Behav. Exp. Financ. 2020, 25, 100281. [CrossRef]

12. Baker, T.; Dellaert, B. Regulating robo advice across the financial services industry. Iowa Law Rev. 2018, 103, 713-750. [CrossRef]

13. Arrow, K.J. The theory of risk aversion. In Essays in the Theory of Risk-Bearing; Markham Publishing Co.: Chicago, IL, USA, 1971; pp. 90-120.

14. Pratt, J.W. Risk Aversion in the Small and in the large. In Uncertainty in Economics; Academic Press: Cambridge, MA, USA, 1978; pp. 59-79.

15. Mongin, P. Expected utility theory. In Handbook of Economic Methodology; Davis, J., Hands, W., Maki, U., Eds.; Edward Elgar: London, UK, 1998; pp. 342-350.

16. Kahneman, D.; Tversky, A. Prospect theory: An analysis of decision under risk. Econometrica 1979, 47, 263-291. [CrossRef]

17. Kahneman, D.; Tversky, A. Prospect theory: An analysis of decision under risk. In Handbook of the Fundamentals of Financial Decision Making: Part I; World Scientific: Toronto, ON, Canada, 2013; pp. 99-127.

18. Rohrmann, B. Risk Attitude Scales: Concepts and Questionnaires; University of Melbourne: Melbourne, Australia, 2002.

19. Pan, C.H.; Statman, M. Questionnaires of risk tolerance, regret, overconfidence, and other investor propensities. J. Investig. Consult. 2012, 13, 54-63. [CrossRef]

20. Michael, A.; Yao, R.; James, R.N., III. An analysis of risk assessment questions based on loss-averse preferences. J. Financ. Couns. Plan. 2015, 26, 17-29.

21. Charles Schwab. Schwab Intelligent Portfolios ${ }^{\mathrm{TM}}$ Investor Profile Questionnaire White Paper. 2020. Available online: https://intelligent.schwab.com/public/intelligent/insights/whitepapers/investor-profile-questionnaire.html (accessed on 25 October 2020).

22. Yook, K.C.; Everett, R. Assessing risk tolerance: Questioning the questionnaire method. J. Financ. Plan. 2003, 16, 48.

23. Elo, S.; Kyngäs, H. The qualitative content analysis process. J. Adv. Nurs. 2008, 62, 107-115. [CrossRef] [PubMed]

24. Boddy, C.R. Sample size for qualitative research. Qual. Mark. Res. 2016, 19, 426-432. [CrossRef]

25. Dworkin, S.L. Sample size policy for qualitative studies using in-depth interviews. Arch. Sex. Behav. 2012, 41, 1319-1320. [CrossRef] [PubMed]

26. Sandelowski, M. Sample size in qualitative research. Res. Nurs. Health 1995, 18, 179-183. [CrossRef] [PubMed]

27. Mason, M. Sample size and saturation in PhD studies using qualitative interviews. Forum Qual. Soc. Res. 2010, 11, 8.

28. Burnard, P. A method of analysing interview transcripts in qualitative research. Nurse Educ. Today 1991, 11, 461-466. [CrossRef]

29. Dey, I. Qualitative Data Analysis: A User Friendly Guide for Social Scientists; Routledge: London, UK, 1993.

30. Stemler, S. An overview of content analysis. Pract. Assess. Res. Eval. 2000, 7, 17.

31. Cordell, D.M. RiskPACK: How to evaluate risk tolerance. J. Financ. Plan. 2001, 14, 36-40.

32. Tertilt, M.; Scholz, P. To advise, or not to advise: How robo-advisors evaluate the risk preferences of private investors. J. Wealth Manag. 2018, 21, 70-84. [CrossRef]

33. Grable, J.E. Financial risk tolerance and additional factors that affect risk taking in everyday money matters. J. Bus. Psychol. 2000, 14, 625-630. [CrossRef]

34. Weber, R.P. Basic Content Analysis, 2nd ed.; Sage: Newbury Park, CA, USA, 1990.

35. Deloitte. Financial Risk Assessment: The Benefits for Clients and Advisers. 2020. Available online: https://www2.deloitte.com/ ie/en/pages/deloitte-private/articles/financial-risk-assessment.html (accessed on 26 October 2020).

36. Wealthfront. Wealthfront Investment Methodology White Paper. 2020. Available online: https://research.wealthfront.com/ whitepapers /investment-methodology/\#13-determining-risk-tolerance (accessed on 26 October 2020).

37. Beketov, M.; Lehmann, K.; Wittke, M. Robo advisors: Quantitative methods inside the robots. J. Asset Manag. 2018, 19, 363-370. [CrossRef]

38. Boreiko, D.; Massarotti, F. How risk profiles of investors affect robo-advised portfolios. Front. Artif. Intell. 2020, 3, 60. [CrossRef]

39. D'Acunto, F.; Prabhala, N.; Rossi, A.G. The promises and pitfalls of robo-advising. Rev. Financ. Stud. 2019, 32, 1983-2020. [CrossRef] 
40. Chu, A.M.Y.; Chau, P.Y.K.; So, M.K.P. Developing a typological theory using a quantitative approach: A case of information security deviant behavior. Commun. Assoc. Inf. Syst. 2015, 37, 25. [CrossRef]

41. Singh, I.; Kaur, N. Wealth management through robo advisory. Int. J. Res. Granthaalayah 2017, 5, 33-43. [CrossRef]

42. Phoon, K.; Koh, F. Robo-advisors and wealth management. J. Altern. Investig. 2018, 20, 79-94. [CrossRef]

43. Niszczota, P.; Kaszás, D. Robo-investment aversion. PLoS ONE 2020, 15, e0239277. [CrossRef]

44. Ahn, W.; Lee, H.S.; Ryou, H.; Oh, K.J. Asset allocation model for a robo-advisor using the financial market instability index and genetic algorithms. Sustainability 2020, 12, 849. [CrossRef]

45. Shanmuganathan, M. Behavioural finance in an era of artificial intelligence: Longitudinal case study of robo-advisors in investment decisions. J. Behav. Exp. Financ. 2020, 27, 100297. [CrossRef] 